\title{
Blood serum mineral element concentrations IT) of weaned Montana ram lambs and their relationship with water quality characteristics
}

\author{
C. M. Page, ${ }^{*}$ T. W. Murphy, ${ }^{*}$ M. L. Van Emon, ${ }^{*}$ J. G. P. Bowman, ${ }^{*}$ S. A. Wyffels, ${ }^{*}$ and W. C. Stewart ${ }^{1}$ \\ *Department of Animal and Range Sciences, Montana State University, Bozeman 59717; and †Department of \\ Animal Science, University of Wyoming, Laramie 82071
}

\begin{abstract}
Clinical and subclinical trace mineral deficiencies can limit productivity in western sheep production systems. The objective of this research was to determine the proportion of ranches that supplemented with trace minerals and to quantify serum trace mineral concentrations in ram lambs after weaning across Montana with particular emphasis on Se and Zn. Serum samples $(\mathrm{n}=214)$ were collected from ram lambs 8 to 10 mo of age $(52.8 \pm 16 \mathrm{~kg})$ at 21 ranches throughout Montana and analyzed for Co, $\mathrm{Cu}, \mathrm{Fe}, \mathrm{Mn}, \mathrm{Mo}, \mathrm{Se}$, and $\mathrm{Zn}$. Ranches were classified as deficient, marginally deficient, adequate, or excessive by flock mean serum trace mineral concentrations. Additionally, water samples were analyzed for pertinent characteristics. The median and interquartile range of serum concentrations for each trace mineral across ranches were as follows: Co $(0.41 \mathrm{ng} / \mathrm{mL} ; 0.90 \mathrm{ng} / \mathrm{mL}), \mathrm{Cu}(0.79 \mu \mathrm{g} / \mathrm{mL}$; $0.24 \mu \mathrm{g} / \mathrm{mL})$, Fe $(153 \mu \mathrm{g} / \mathrm{dL} ; 52 \mu \mathrm{g} / \mathrm{dL}), \mathrm{Mn}(1.70 \mathrm{ng} / \mathrm{mL}$; $0.80 \mathrm{ng} / \mathrm{mL})$, Mo (15.3 ng/mL; $19.3 \mathrm{ng} / \mathrm{mL})$, Se (115 ng/ $\mathrm{mL} ; 97.5 \mathrm{ng} / \mathrm{mL})$, and $\mathrm{Zn}(0.70 \mu \mathrm{g} / \mathrm{mL}, 0.19 \mu \mathrm{g} / \mathrm{mL})$. Of ranches surveyed, $67 \%$ provided a trace mineral supplement. Ranches that provided supplementary trace mineral had greater serum Se concentrations $(P<0.001)$. The 2 most commonly deficient and marginally deficient minerals across Montana were Se $(19 \%$ of ranches deficient; $23.8 \%$ of ranches marginally deficient) and Zn (9.5\% of ranches deficient; $57.1 \%$ of ranches marginally deficient). Regionally, Se serum samples classified as deficient were all located in western Montana. Of ranches sampled, 40 and $35 \%$ of water samples exceeded upper desired concentrations for $\mathrm{Na}$ and sulfates, respectively.
\end{abstract}

Key words: Montana, ram lamb, selenium, sheep, zinc

\section{INTRODUCTION}

Sheep operations in the western United States rely on rangelands as their primary feed source, which could lead

\footnotetext{
The authors declare no conflict of interest.

${ }^{1}$ Corresponding author: Whit.Stewart@uwyo.edu
}

to clinical or subclinical trace mineral deficiencies and limit animal productivity. Minerals perform essential functions including structural, physiological, catalytic, and regulatory roles (Suttle, 2010). Forage trace mineral concentrations are highly variable across rangelands because they are largely influenced by soil geochemistry and plant stage of maturity (Mathis and Sawyer, 2004; Smith et al., 2014; Jones and Tracy, 2015).

Montana consists of $380,832 \mathrm{~km}^{2}$ of diverse geography, resulting in a high potential for variability of trace mineral concentrations of rangelands and feedstuffs. Additionally, Montana has an estimated 200,000 total breeding sheep, which was the fifth largest inventory in the United States (USDA-NASS, 2017). Previous research reported Se and Zn concentrations in forages across the western United States were less than adequate for animal health and performance (Dargatz and Ross, 1996; Mathis and Sawyer, 2004). Mineral deficiencies in sheep, particularly Se and Zn, have negative effects on reproductive performance and longevity (Suttle, 2010), which may present potential production losses. Additionally, selection programs have resulted in increased growth performance and greater mature BW (Notter, 1998; Burton et al., 2015), which may necessitate greater precision in trace mineral nutrition management.

No previous study has quantified trace mineral status in western US breeding sheep populations. Therefore, the objective of this research was to quantify serum trace mineral concentrations in Montana ram lambs after weaning with particular emphasis on Se and Zn. It was hypothesized that mineral supplementation strategies and serum trace mineral concentrations would vary across flocks sampled, and Se and Zn serum concentrations would be less than adequate.

\section{MATERIALS AND METHODS}

\section{Experimental Design}

The experimental protocol for this study was approved by the Agricultural Animal Care and Use Committee of Montana State University (2016-AA04). This study was conducted from September 24 to November 23, 2015. 


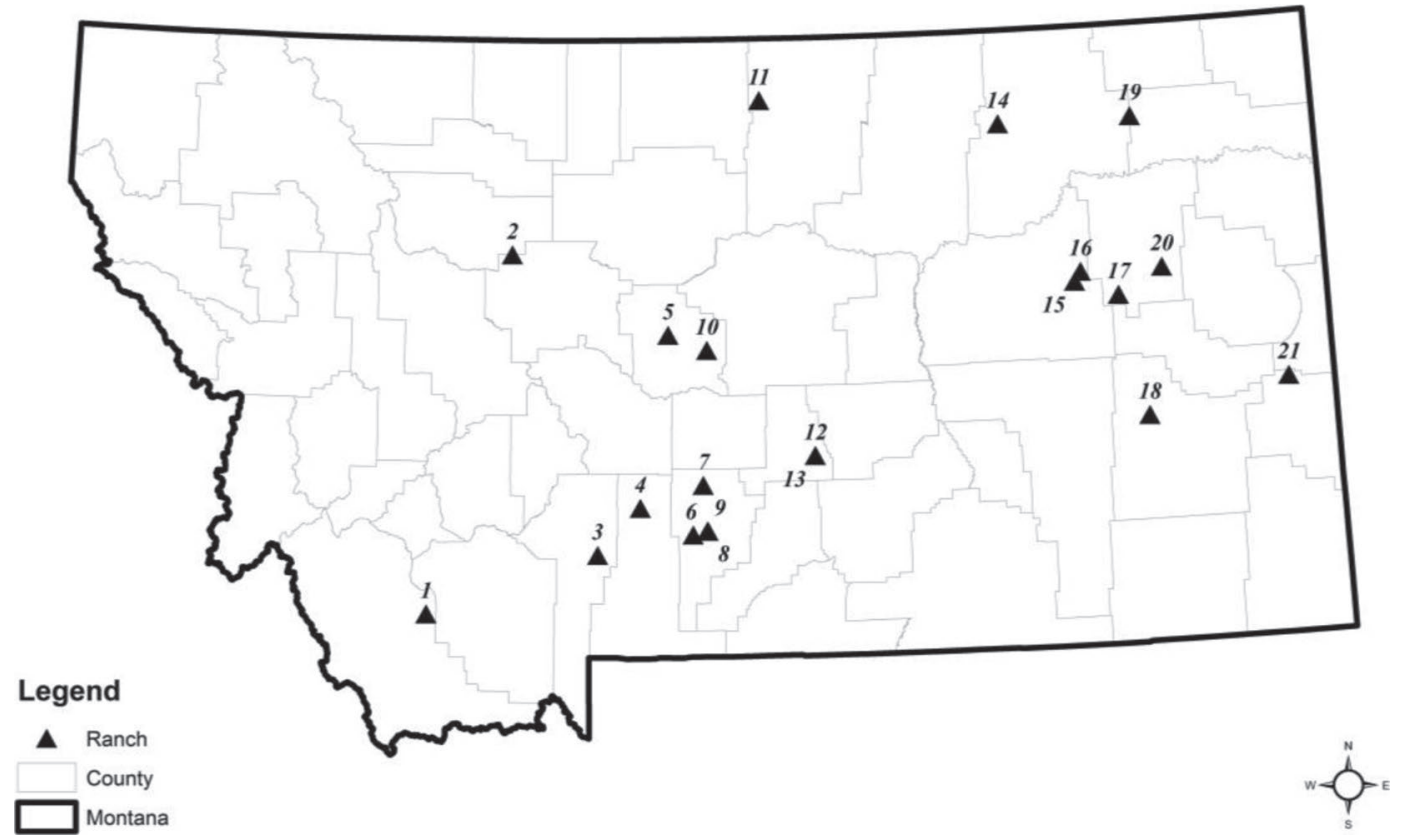

Figure 1. Map of sampling locations across Montana.

Twenty-one seedstock operations located across 15 counties and a wide range of production environments in Montana were sampled. Locations spanned from Dillon $\left(45.2158^{\circ} \mathrm{N}, 112.6342^{\circ} \mathrm{W}\right)$ to Wolf Point $\left(48.0914^{\circ} \mathrm{N}\right.$, $105.6425^{\circ} \mathrm{W}$ ), representing a distance of approximately $805 \mathrm{~km}$ (Figure 1).

Participating ranches were selected for sampling based on their intent for developing and marketing rams to commercial operations. A homogeneous age group of 8- to 10 -mo-old rams $(52.8 \pm 16 \mathrm{~kg})$ were sampled within 2 mo after weaning to broadly assess trace mineral status across the state. This subpopulation of ram lambs was sampled due to similar developmental stage at a time of year when dietary trace mineral consumed came from late-season forages or harvested feedstuffs. A total of 214 rams were randomly sampled across ranches for analysis. Breed composition of the rams included Targhee $(\mathrm{n}=95)$, Rambouillet $(\mathrm{n}=47)$, Columbia $(\mathrm{n}=20)$, Suffolk $(\mathrm{n}=$ 12), Hampshire $(\mathrm{n}=15)$, other fine-wool breeds $(\mathrm{n}=5)$, and various crosses $(\mathrm{n}=20)$. Within each ranch, at least $15 \%$ of the ram lamb population was sampled, following recommendations for adequate sample size by Herdt and Hoff (2011).

All blood samples were collected via jugular venipuncture into $13 \times 100 \mathrm{~mm}$ trace mineral royal blue top vacutainer tubes (Covidien, Mansfield, MA) without any additives. Blood was centrifuged at $1,573 \times g$ at $20^{\circ} \mathrm{C}$ for 15 min approximately $4 \mathrm{~h}$ after collection (Herdt and Hoff, 2011), and serum was decanted into 2 aliquots in 2-mL tubes and stored at $-20^{\circ} \mathrm{C}$ for later analyses. Samples that had a significant amount of hemolysis were not used in the laboratory analysis. Serum samples were shipped on ice overnight for trace mineral analysis at a commercial laboratory (Michigan State University Diagnostic Center for Population and Animal Health, East Lansing). Cobalt, $\mathrm{Cu}, \mathrm{Fe}, \mathrm{Mn}, \mathrm{Mo}$, Se, and Zn concentrations in serum were quantified using an ionized coupled plasma mass spectrometry method (Wahlen et al., 2005).

Operators at each location were surveyed on whether ram lambs were offered a trace mineral supplement to evaluate supplementation effects on serum trace mineral concentrations. Instances where ranches only provided a source of $\mathrm{NaCl}$ and not a trace mineral supplement were classified as unsupplemented. If supplementation occurred, there was no attempt to distinguish consumption or supplementation levels. Due to logistical and financial limitations, basal dietary trace mineral concentrations were not collected or analyzed from harvested feedstuffs or rangeland plant communities. Serum trace mineral concentrations were classified as deficient, marginally deficient, adequate, and excessive based on reference ranges established at Michigan State University, Diagnostic Center for Population and Animal Health (Table 1).

Samples $(500 \mathrm{~mL})$ were collected from the water source used by ram lambs at each ranch and analyzed by a commercial laboratory (Midwest Laboratories Inc., Omaha, NE) for livestock suitability (package W1 livestock suitability). Water characteristics included $\mathrm{Ca}, \mathrm{Cu}, \mathrm{Fe}, \mathrm{Mg}$, $\mathrm{Na}$, chloride, nitrate-nitrogen, sulfate, and total dissolved solid content as well as $\mathrm{pH}$ and conductivity. Water characteristics were quantified using a light emission technique where prepared samples are injected into a high energy plasma that forces the elements in the injected sample to emit light wavelengths that are specific to each metal present. Ions of aqueous samples are separated and measured for conductivity. 
Table 1. Criteria for classification of ranches based on blood serum concentrations ${ }^{1}$

Blood serum concentration

\begin{tabular}{lccccccc}
\cline { 2 - 7 } Classification & $\mathbf{C o}, \mathbf{n g} / \mathbf{m L}$ & $\mathbf{C u}, \boldsymbol{\mu g} / \mathbf{m L}$ & $\mathbf{F e}, \boldsymbol{\mu g} / \mathbf{d L}$ & $\mathbf{M n}, \mathbf{n g} / \mathbf{m L}$ & $\mathbf{M o}, \mathbf{n g} / \mathbf{m L}$ & $\mathrm{Se}, \mathbf{n g} / \mathbf{m L}$ & $\mathbf{Z n}, \boldsymbol{\mu g} / \mathbf{m L}$ \\
\hline Deficient & - & $<0.50$ & $<77.0$ & - & - & $<50.0$ & $<0.60$ \\
Marginally deficient & - & $0.50-0.70$ & $77.0-116.0$ & - & - & $50.0-110.0$ & $0.60-0.80$ \\
Adequate & $>0.10$ & $0.70-1.00$ & $116.0-122.0$ & $0.50-2.00$ & $12.0-30.0$ & $110.0-160.0$ & $0.80-1.20$ \\
Excessive & - & $>1.00$ & $>122.0$ & - & - & $>160.0$ & $>1.20$ \\
\hline
\end{tabular}

${ }^{1}$ Reference ranges were adapted from Herdt and Hoff (2011) and Michigan State University Diagnostic Center for Population and Animal Health (East Lansing). Michigan State University Diagnostic Center for Population and Animal Health does not have robust criteria for $\mathrm{Co}, \mathrm{Mn}$, and Mo serum concentrations.

\section{Statistical Analyses}

Individual outliers of serum trace mineral concentration within each ranch were first identified and removed from the data. Values were considered outliers if they fell 1.5 $\times$ interquartile range (IQR) below the second quantile or $1.5 \times \mathrm{IQR}$ above the fourth quantile for each trace mineral. Descriptive statistics (median and IQR) of serum trace mineral concentrations were estimated within and across ranch using the MEANS procedure of SAS (version 9.4; SAS Institute Inc., Cary, NC). A Shapiro-Wilk test of normality was first performed in R (R Core Team, 2016), and it was determined that no serum trace minerals were normally distributed $(P<0.001)$. The MASS package of $\mathrm{R}$ (Venables and Ripley, 2002) and the Box-Cox function were then used to find a suitable transformation for each serum trace mineral.

To determine the effect of supplementation on serum trace mineral concentration, ranch was considered the experimental unit, and mean transformed serum trace mineral concentration was analyzed in the GLM procedure with the fixed effect of mineral supplementation (supplemented or unsupplemented). Pearson correlation coefficients among individual-ram-lamb transformed serum trace mineral concentrations were estimated using the CORR procedure. Additionally, Pearson correlation coefficients among ranch mean transformed serum Se and Zn concentrations and water quality characteristics were also estimated. Least squares means were considered different from each other and correlation coefficients different from zero at $P \leq 0.05$, and a tendency was considered at $P \leq$ 0.10 .

\section{RESULTS AND DISCUSSION}

Cooperative field studies help producers and scientists understand in-field management practices and responses, specifically, mineral supplementation strategies, trace mineral concentrations in feedstuffs, mineral deficiencies in the animal, and the effects of supplementation on animal status (Dargatz and Ross, 1996; Menzies et al., 2003; Ademi et al., 2017; Keady et al., 2017). Dietary mineral concentrations are often quantified but do not equate directly to animal status, so biological samples must be taken (Dargatz and Ross, 1996; Herdt and Hoff, 2011; Ademi et al., 2017). Serum trace mineral concentrations have their own set of limitations when evaluating status of an animal. For example, Zn serum concentrations can be influenced by hyperthermal stress or immune function (Wegner et al., 1973; Kincaid, 2000). However, serum trace mineral concentrations have been useful when investigating population trace mineral status as a practical and less invasive method. When feasible, mineral status should be evaluated based on specific mineral concentrations of tissues that have been identified as storage pools for a particular mineral (Suttle and Angus, 1976; Langlands et al., 1984; Vermunt and West, 1994).

Medians and IQR of $\mathrm{Co}, \mathrm{Cu}, \mathrm{Fe}, \mathrm{Mn}, \mathrm{Mo}$, Se, and $\mathrm{Zn}$ within ranch are reported in Table 2. Median, IQR, percentage of samples less than the lower limit of the suggested adequate range, and $\lambda$ of serum concentrations from all 214 samples are reported in Table 3 . The serum trace minerals with the greatest variation across ranches were Co, Mn, and Mo with IQR of $0.90,0.80$, and 19.3, respectively. Of Montana ranches surveyed, only $67 \%$ provided a trace mineral supplement. Trace minerals in animal feedstuffs are the most highly variable nutrient due to factors of plant species, soil, stage of maturity, and climate conditions (Underwood, 1981; Berger, 1996), emphasizing the importance of producer feed analysis and need for supplementation. Supplemental minerals can have positive effects on animal reproduction, immunity, and feed intake (McDowell, 1996; Hall et al., 2013; Keady et al., 2017). However, inadequate intake may result in subclinical deficiencies, which are difficult to detect because of discrete clinical signs (Cloete et al., 1999). Inadequate mineral intake can decrease forage consumption and feed efficiency (Aliarabi et al., 2015), reproductive efficiency (Martin and White, 1992), and disease resistance (Weiss et al., 1990). Bowman and Sowell (1997) outlined factors influencing variation in free-choice supplement such as supplemental type and delivery method, as well as animal factors including experience and breed. Anecdotally, producers might 
not supplement with a trace mineral package because of cost and perceived return on investment, weatherization and subsequent inedibility, and difficulty of supplementing in rotational or extensive grazing systems. The effect of supplementation on trace mineral concentration in ram lamb serum is reported in Table 4. Serum concentrations of individual trace minerals are discussed in further detail in the following.

\section{Serum Co}

Provision of a mineral supplement across ranches sampled had no effect $(P=0.17)$ on serum Co concentrations of weaned ram lambs. Interquartile range of blood serum Co concentrations was $0.90 \mathrm{ng} / \mathrm{mL}$ with a median of 0.41 $\mathrm{ng} / \mathrm{mL}$. Across Montana, all ranches were classified as adequate in Co with mean serum concentrations meeting or exceeding $0.10 \mathrm{ng} / \mathrm{mL}$. Liver tissue and blood have been used to quantify Co status in sheep, generally with blood being more responsive to nutritional changes in Co concentrations (Suttle, 2010; Keady et al., 2017).

Mammalian tissues are not known to have specific requirements for $\mathrm{Co}$, but it is required by rumen microorganisms for synthesis of vitamin $\mathrm{B}_{12}$ (NRC, 2007), which catalyzes activity of methylmalonyl-CoA mutase and methionine synthase (Kennedy et al., 1992). Methionine synthase is necessary for rumen microbes to produce propionate, a metabolite that is a major determinant of the host's Co responsiveness (Suttle, 2010) and the only gluconeogenic volatile fatty acid. Keady et al. (2017) observed decreased days to slaughter in lambs receiving Co supplementation, and response to supplementation increased further into the grazing season. Comparatively, lambs that did not receive Co supplementation had greater BW variation (Keady et al., 2017). Recommended dietary concentrations of $\mathrm{Co}$ are between 0.10 and $0.20 \mathrm{mg} / \mathrm{kg}$ for sheep (NRC, 2007). Diets containing legumes generally have higher concentrations of Co than do diets containing grasses, followed by those containing grains, which are usually poor sources (NRC, 2007).

\section{Serum $\mathrm{Cu}$}

Provision of a mineral supplement across ranches sampled had no effect $(P=0.65)$ on serum $\mathrm{Cu}$ concentrations of weaned ram lambs, which was expected because sheep mineral sold in the United States rarely contains added $\mathrm{Cu}$. Copper serum concentration IQR was $0.24 \mu \mathrm{g} / \mathrm{mL}$ with a median of $0.79 \mu \mathrm{g} / \mathrm{mL}$. However, serum $\mathrm{Cu}$ concentrations are of little use in interpreting status because concentrations can be highly variable, unless clinical deficiency is being diagnosed in tandem (Vermunt and West, 1994). Nevertheless, the mean serum $\mathrm{Cu}$ concentrations were within an adequate range (Table 1 ). There were no ranches sampled that were classified as deficient in serum $\mathrm{Cu}$ concentrations, but $19 \%$ were classified as marginally deficient, $71.4 \%$ adequate, and $9.5 \%$ excessive. The au- thors acknowledge that liver biopsies would have been a superior indicator of $\mathrm{Cu}$ status (Kincaid, 2000), but due to the collection of samples from privately owned stud prospects, time constraints, and resources, liver biopsies were not feasible.

Copper is an essential trace mineral involved in many enzyme activities, including ATP production, collagen and bone formation, and optimal nervous system function (McDowell, 2017). Regions around the world have been identified as deficient in $\mathrm{Cu}$, and deficiencies in gestating ewes can cause ataxia in lambs and impaired leukocyte function (Bennetts and Chapman, 1937; Jones and Suttle, 1981). Historically, dietary $\mathrm{Cu}$ recommendations were 7 to $11 \mathrm{mg} / \mathrm{kg}$ of $\mathrm{DM}$, but current dietary recommendations are based off of a factorial method that takes into account physiological status (i.e., growing, gestating, or lactating) of the animal and factors that affect $\mathrm{Cu}$ absorption (NRC, 2007). Rams grazing dormant cool- and warm-season grasses might experience a copper shortage because these are known to contain copper concentrations of 2 to $5 \mathrm{mg} / \mathrm{kg}$ (Karn and Hofmann, 1990; Grings et al., 1996). Nutritional management of $\mathrm{Cu}$ should also include consideration of Mo, S, and Fe because interaction and decreased bioavailability may result. For example, rams housed in confinement with high levels of $\mathrm{Cu}$ and inadequate amounts of Mo and $\mathrm{S}$ were more susceptible to $\mathrm{Cu}$ toxicity than animals on pasture (Buck and Sharma, 1969). On the contrary, antagonistic $\mathrm{Cu}$ absorption due to excessive dietary $\mathrm{Fe}$ has resulted in $\mathrm{Cu}$-deficient enzootic ataxia (de Sousa et al., 2012), and similar instances would warrant additional $\mathrm{Cu}$ supplementation.

\section{Serum Fe}

Provision of a mineral supplement across ranches sampled had no effect $(P=0.42)$ on serum Fe concentrations among weaned ram lambs, and all ranches were classified as either adequate or excessive. Serum Fe concentration IQR was $52 \mu \mathrm{g} / \mathrm{dL}$ with a median of $153 \mu \mathrm{g} / \mathrm{dL}$. Many ranches were actually within the excessive range for serum Fe concentration $(90.5 \%)$, which may indicate a potential for antagonism with $\mathrm{Cu}$ and $\mathrm{S}$. However, Fe toxicity in ruminants is rarely experienced because of limited absorption when levels are high in diets (Herdt and Hoff, 2011). Both liver and serum concentrations are normally used as indicators of Fe status in animals because depletion of serum concentrations occurs just before anemia in deficient animals.

Iron is the most abundant trace mineral in the body, and approximately $60 \%$ of it is found in hemoglobin, which is essential to $\mathrm{O}_{2}$ and $\mathrm{CO}_{2}$ transportation (NRC, 2007). Forages show marked seasonality in Fe concentrations with peaks in spring and autumn, although most livestock feeds contain high concentrations of $\mathrm{Fe}$, resulting in few cases of deficiencies (Suttle, 2010). Suggested NRC (2007) dietary recommendations for Fe are $55 \mathrm{mg} / \mathrm{kg}$ for growing sheep. 


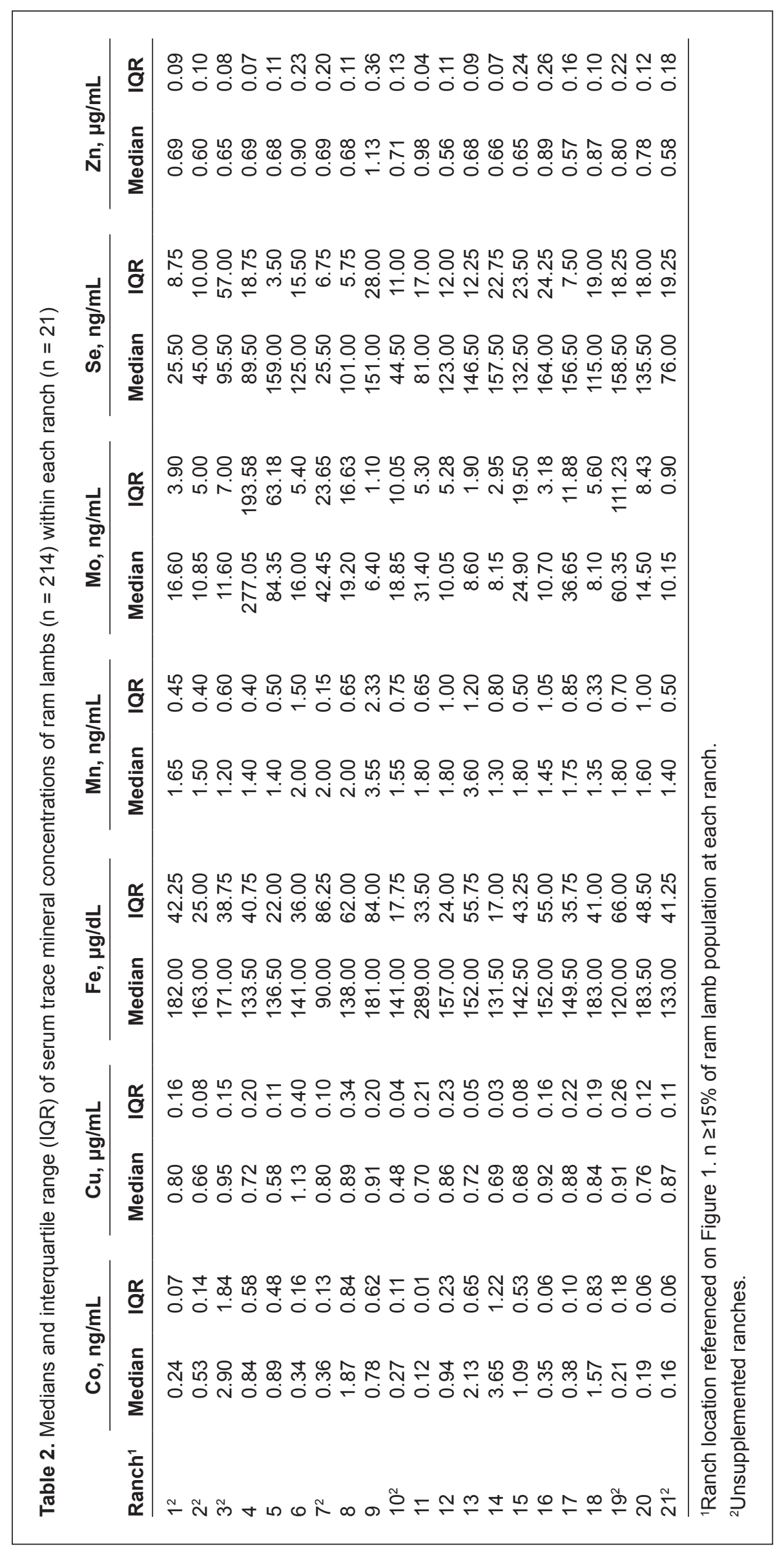


Table 3. Median, interquartile range (IQR), percentage of samples less than the lower limit of the suggested adequate range (inadequate), and $\lambda$ value that maximizes the log-likelihood of the Box-Cox transformation of serum trace mineral concentrations from Montana ram lambs ( $\mathrm{n}$ $=214$ ) measured across ranches

\begin{tabular}{lcccc} 
Trace mineral & Median & IQR & $\begin{array}{c}\text { Inadequate, } \\
\%\end{array}$ & \multicolumn{1}{c}{$\boldsymbol{\Lambda}$} \\
\hline $\mathrm{Co}, \mathrm{ng} / \mathrm{mL}$ & 0.41 & 0.90 & 0 & -0.22 \\
$\mathrm{Cu}, \mu \mathrm{g} / \mathrm{mL}$ & 0.79 & 0.24 & 27.8 & -0.10 \\
$\mathrm{Fe}, \mu \mathrm{g} / \mathrm{dL}$ & 153.0 & 52.0 & 14.1 & 0.59 \\
$\mathrm{Mn}, \mathrm{ng} / \mathrm{mL}$ & 1.70 & 0.80 & 0 & -0.26 \\
$\mathrm{Mo}, \mathrm{ng} / \mathrm{mL}$ & 15.3 & 19.3 & 36.2 & -0.46 \\
$\mathrm{Se}, \mathrm{ng} / \mathrm{mL}$ & 115.0 & 97.5 & 46.3 & 0.71 \\
$\mathrm{Zn}, \mu \mathrm{g} / \mathrm{mL}$ & 0.70 & 0.19 & 74.3 & -0.51 \\
\hline
\end{tabular}

${ }^{1}$ Adequate reference ranges were adapted from the study by Herdt and Hoff (2011) and the Michigan State University Diagnostic Center for Population and Animal Health (East Lansing; Table 1).

\section{Serum Mn}

Providing a mineral supplement had no effect $(P=0.16)$ on serum Mn concentrations in the ranches sampled. Serum $\mathrm{Mn}$ concentration IQR was $0.80 \mathrm{ng} / \mathrm{mL}$ with a median of $1.7 \mathrm{ng} / \mathrm{mL}$. The average serum Mn concentration across sampled Montana ram lambs was higher than the adequate range. However, $\mathrm{Mn}$ toxicity is rare in ruminants, even at high dietary concentrations (NRC, 2007).

Liver, whole blood, and serum are the most frequently sampled sites to quantify Mn concentrations (Kincaid, 2000). Plasma Mn concentrations are maintained within a narrow range $(5-10 \mu \mathrm{g} / \mathrm{L})$ in cattle, even while consuming diets with a wide range of $\mathrm{Mn}$ concentrations (40-1,000 $\mathrm{mg} / \mathrm{kg}$ ). This is in part due to the ability of the liver to remove excess quantities of $\mathrm{Mn}$, and the relatively fast depletion from tissues including liver (Gibbons et al., 1976; Black et al., 1985). Functions of Mn include involvement in bone development; protection against oxidative tissue damage; and carbohydrate, fat, and protein biochemical processes (Herdt and Hoff, 2011). Testicular growth is believed to be optimized with 19 to $30 \mathrm{mg} / \mathrm{kg}$ (Masters et al., 1988), a range that is similar for obtaining adequate growth in sheep (20-25 mg/kg; NRC, 2007).

\section{Serum Mo}

Additional supplementation of mineral to the basal diet had no effect $(P=0.77)$ on serum Mo concentrations of weaned ram lambs. Serum Mo concentration IQR was 19.3 $\mathrm{ng} / \mathrm{mL}$ with a median of $15.3 \mathrm{ng} / \mathrm{mL}$. A large variation in serum Mo concentrations was observed within $(\mathrm{CV}=$ $52 \%)$ and across ranches $(\mathrm{CV}=179 \%)$. Conclusions for this large variation are hard to verify in the absence of dietary trace mineral concentrations. However, US geological survey soil mineral data indicated the ranch that was greatest in serum Mo concentration (median, $277 \mathrm{ng} / \mathrm{mL}$; IQR $193.58 \mathrm{ng} / \mathrm{mL}$ ) was located in areas with high soil Mo concentrations, unique from other sampling locations (Smith et al., 2014). Dietary Mo concentrations are adequately reflected in serum Mo concentrations, although use of serum for assessment is generally only used when Mo toxicity or $\mathrm{Cu}$ deficiency is a concern (Kincaid, 2000). However, a dearth of data regarding serum Mo concentrations currently exists, and data contained herein will aid in guiding future reference ranges for sheep.

Molybdenum is an essential trace mineral because of its role in the reduction of nitrate to nitrite in bacteria (Williams and Da Silva, 2002), though essential requirements are low and clear signs of deficiencies have been reported in few species (McDowell, 2017). Toxicity of Mo in ruminants varies by species, chemical form, type of diet, and $\mathrm{S}$ concentration in diet (NRC, 2007).

\section{Serum Se}

Serum Se concentrations were greater $(P<0.001)$ on ranches that supplemented mineral $(131.47 \mathrm{ng} / \mathrm{mL})$ than on those that did not $(64.11 \mathrm{ng} / \mathrm{mL})$. Frequencies of serum Se concentration class within and across supplementation program are reported in Table 5. Across ranches surveyed, $19 \%$ were deficient, $23.8 \%$ marginally deficient, $42.9 \%$ adequate, and $14.3 \%$ excessive. Within ranches that did not supplement a mineral premix, the majority of ranch mean

Table 4. Back-transformed least squares means for the main effect of mineral supplementation (supplemented or unsupplemented) on ranch serum trace mineral concentration

\begin{tabular}{lccc} 
Trace $\mathbf{m i n e r a l}$ & Supplemented $(\mathbf{n}=\mathbf{1 4})$ & Unsupplemented $(\mathbf{n}=\mathbf{7})$ & $\boldsymbol{P}$-value \\
\hline $\mathrm{Co}, \mathrm{ng} / \mathrm{mL}$ & 0.63 & 0.35 & 0.17 \\
$\mathrm{Cu}, \boldsymbol{\mu g} / \mathrm{mL}$ & 0.80 & 0.77 & 0.65 \\
$\mathrm{Fe}, \boldsymbol{\mu g} / \mathrm{dL}$ & 158.67 & 144.95 & 0.42 \\
$\mathrm{Mn}, \mathrm{ng} / \mathrm{mL}$ & 1.79 & 1.55 & 0.16 \\
$\mathrm{Mo}, \mathrm{ng} / \mathrm{mL}$ & 15.08 & 16.79 & 0.77 \\
$\mathrm{Se}, \mathrm{ng} / \mathrm{mL}$ & 131.47 & 64.11 & $<0.001$ \\
$\mathrm{Zn}, \boldsymbol{\mu g} / \mathrm{mL}$ & 0.72 & 0.62 & 0.34
\end{tabular}


serum Se concentrations were either deficient $(57.1 \%)$ or marginally deficient $(28.6 \%)$. However, within ranches that did supplement a mineral premix, most ranch mean serum Se concentrations were either adequate $(64.3 \%)$ or excessive $(14.3 \%)$. Though not quantified in the present study, regional Se deficiencies were observed; serum concentrations were lower in Montana ranches near the eastern front of the Rocky Mountains in association with lower soil mineral concentrations (Smith et al., 2014) and previous estimates of forage Se concentrations (NRC, 1983). This regional dynamic of decreased Se serum concentrations in western Montana has been corroborated through producer polling conducted via extension programing throughout western Montana. Thus, efforts to improve precision of supplementation of Se in these areas is warranted (W. C. Stewart, 2016, Montana State University, Bozeman, personal communication). Selenium deficiencies in sheep have been well documented globally, along with low Se concentrations in forages (Dargatz and Ross, 1996; Ademi et al., 2017). Sheep whole blood Se concentrations in Kosovo were positively affected by supplementation, independent of supplementation type including injectable, mineral block, mineral premixes, and feed compounds (Ademi et al., 2017). Greater bioavailability and retention of Se is achieved through organic sources (selenomethionine, selenocysteine) compared with inorganic (sodium selenite, sodium selenite), which should be considered in operations where supplement delivery methods are a challenge (Hall et al., 2009, 2013; Stewart et al., 2012b).

Results suggest the median serum Se concentrations are within adequate reference ranges (Table 3) but approach marginal status. Clinical signs of Se deficiency are often manifested as nutritional myopathy (i.e., white muscle disease) but can also result in production losses in subclinical instances. Marginal (subclinical) Se deficiencies can result in decreased growth performance, loss of milk yield, decreased reproductive performance, and reduced wool production but can be remedied with Se supplementation (Slen et al., 1961; Gabbedy, 1971; McDonald, 1975; Suttle, 2010). Selenium dietary recommendations are $0.5 \mathrm{mg} / \mathrm{kg}$ of live weight gain, and this amount is divided by the absorption coefficient (NRC, 2007). However, other studies indicate and recommend that additional supplementation could be beneficial to ewe and lamb performance (Langlands et al., 1991; Stewart et al., 2012a). Current FDA allowance of Se is not to exceed $0.3 \mathrm{mg} / \mathrm{kg}$ for complete feeds, or $90 \mathrm{mg} / \mathrm{kg}$ in a salt-mineral mixtures being fed at $0.7 \mathrm{mg}$ per head per day (FDA, 2004; NRC, 2007).

\section{Serum Zn}

Additional supplementation of mineral to the basal diet had no effect $(P=0.34)$ on serum $\mathrm{Zn}$ concentrations of weaned ram lambs. Serum Zn concentration IQR was 0.19 $\mu \mathrm{g} / \mathrm{mL}$ with a median of $0.70 \mu \mathrm{g} / \mathrm{mL}$. Ranch mean serum Zn concentrations indicated $9.5 \%$ of ranches were deficient, $57.1 \%$ marginally deficient, $33.3 \%$ adequate, and none excessive. In general, production losses from animals classified as marginally deficient are difficult to quantify because subclinical signs such as mild hypophagia and subsequent reduced growth performance, decreased wool growth, and lower fertility (Underwood and Somers, 1969; Martin and White, 1992; White et al., 1994) are not generally quantified and prescriptively remedied at the ranch level. Of the 214 sheep sampled in the study, $74.3 \%$ were inadequate in serum Zn concentrations. As stated previously in the discussion, Zn serum concentration is affected by both infectious and noninfectious stress or hemolysis in serum concentrations (Wegner et al., 1973; Kincaid, 2000), although it is often used for indicating Zn status of animals.

The results of the current study agree with findings from Ademi et al. (2017), who reported no effect of supplementation on whole blood $\mathrm{Zn}$ concentrations in eastern Europe. Considerations should include Zn source bioavailability in mineral supplements, because organic sources of a mineral are generally identified as more bioavailable than inorganic sources (Rojas et al., 1995; Spears, 2003). Zinc is the second most abundant trace mineral in the body with important functions involved in reproduction

Table 5. Frequency of Se status class across 21 Montana sheep operations within and across supplementation program

\begin{tabular}{lcccc} 
& \multicolumn{4}{c}{ Classification ${ }^{1}$} \\
\cline { 2 - 5 } Ranches & Deficient, \% & $\begin{array}{c}\text { Marginally } \\
\text { deficient, \% }\end{array}$ & Adequate, \% & Excessive, \% \\
\hline Supplemented $(\mathrm{n}=14)$ & 0.0 & 21.4 & 64.3 & 14.3 \\
Unsupplemented $(\mathrm{n}=7)$ & 57.1 & 28.6 & 0.0 & 14.3 \\
Total $(\mathrm{n}=21)$ & 19.0 & 23.8 & 42.9 & 14.3 \\
\hline
\end{tabular}

${ }^{1}$ Reference ranges were adapted from the study by Herdt and Hoff (2011) and the Michigan State University Diagnostic Center for Population and Animal Health (East Lansing): deficient: $<50 \mathrm{ng} / \mathrm{mL}$; marginally deficient: 50 to $110 \mathrm{ng} / \mathrm{mL}$; adequate: 110 to $160 \mathrm{ng} / \mathrm{mL}$; excessive: $>160 \mathrm{ng} / \mathrm{mL}$. 
Table 6. Estimated Pearson correlation coefficients between serum trace mineral concentrations of individual ram lambs $(n=214)$ across ranches

\begin{tabular}{llllllll} 
& Co & Cu & Fe & Mn & Mo & Se & Zn \\
\hline Co & 1.00 & -0.06 & $-0.19^{*}$ & 0.11 & $-0.25^{*}$ & $0.35^{*}$ & $-0.14^{*}$ \\
$\mathrm{Cu}$ & - & 1.00 & -0.06 & 0.04 & -0.08 & $0.16^{*}$ & $0.20^{*}$ \\
$\mathrm{Fe}$ & - & - & 1.00 & 0.05 & -0.11 & -0.12 & $0.32^{*}$ \\
$\mathrm{Mn}$ & - & - & - & 1.00 & -0.05 & $0.14^{*}$ & 0.09 \\
$\mathrm{Mo}$ & - & - & - & - & 1.00 & -0.09 & -0.04 \\
$\mathrm{Se}$ & - & - & - & - & - & 1.00 & 0.12 \\
$\mathrm{Zn}$ & - & - & - & - & - & - & 1.00 \\
\hline
\end{tabular}

*Estimated Pearson correlation coefficient is different from zero $(P \leq 0.05)$.

(Kumar et al., 2006), gene expression (Berg, 1990), immune function (Spears and Weiss, 2008), and wool growth in sheep (White et al., 1994).

Cool-season grasses decrease in Zn concentration as the grazing season progresses; plants go into a state of dormancy and decrease in digestibility (Rauzi et al., 1969; Jones and Tracy, 2015). Some of these plants include Montana native grasses Blue Grama (Bouteloua gracilis) and Western Wheatgrass (Pascopyrum smithii; Rauzi et al., 1969; Jones and Tracy, 2015). Late summer and autumn coincide with major production periods (i.e., weaning, breeding, and marketing lambs) for many western US sheep ranches, and it is likely that the dietary Zn shortfall combined with increased physiological demands may result in clinical and subclinical deficiencies. Zinc supplementation is warranted and may be beneficial during times when producers are relying on dormant rangelands or harvested forages to supply adequate dietary Zn concentrations.

Optimal concentrations of dietary Zn for sheep are not well understood. However, the high tolerance of sheep to dietary Zn (300 mg of Zn/kg of diet DM; NRC, 2005) indicates potential for increased dietary Zn concentrations above the suggested range of 24 to $51 \mathrm{mg} / \mathrm{kg}$ of DM for growing animals (NRC, 2007). Furthermore, increased levels might be warranted to match requirements with the desired level of performance. Page et al. (2017) reported greater wool growth and ADG in rams consuming increased concentrations of dietary $\mathrm{Zn}(>90 \mathrm{mg} / \mathrm{kg}$ of DM). The tissues of the testes contain high concentrations of $\mathrm{Zn}$ and are affected by low dietary Zn levels, which can reduce male reproductive efficiency (Apgar, 1992). The effect of Zn deficiency on reproductive function appears to be more prominent in males than in females, possibly because of the enzymes involved in steroidogenesis (Martin and White, 1992; Martin et al., 1994).

\section{Relationships Among Serum Trace Mineral Concentrations}

Estimated Pearson correlation coefficients between serum trace mineral concentrations using individual ram lamb records are reported in Table 6. Serum Se was mod- erately and positively correlated $(0.35 ; P<0.001)$ with serum Co. Serum Se was positively correlated $(P<0.05)$ with serum $\mathrm{Cu}(0.16)$. Additionally, serum Se was positively correlated $(P<0.05)$ with serum $\mathrm{Mn}$; however, the magnitude of the correlation coefficient was low (0.14). Grace and Lee (1990) reported increased tissue Se and Mn concentrations that coincided with increasing dietary concentrations. Serum Co had negative correlations $(P<$ $0.05)$ with serum $\mathrm{Fe}(-0.19)$ and Mo $(-0.25)$. A tendency for correlations $(P<0.07)$ was also found between serum $\mathrm{Zn}$ and serum Co (-0.14), Cu (0.20), and Fe (0.32); however, the absolute values were all low. Pearson correlation coefficients between all other pairs of serum trace minerals were not significantly different from zero $(P>0.10)$.

\section{Water Characteristics}

Water samples were analyzed for livestock suitability from 20 of the participating ranches, and quality characteristics are reported in Table 7. Extremes in water quality indicators can affect the biological availability of certain trace minerals due to potential antagonist interactions between minerals (NRC, 2005). However, interpreting antagonistic relationships from water quality is challenging in the current field survey study because water or mineral intake was not quantified. Furthermore, water quality can be difficult to define because it is influenced by taste, smell, turbidity, and electrical conductivity (Socha et al., 2003). Nevertheless, the current study does offer a base of knowledge to interpret how water quality may effect trace mineral status.

In the current study, water $\mathrm{Na}$, sulfate, and $\mathrm{pH}$ exceeded maximum tolerable levels in 40,35, and $20 \%$ of sampled ranches, respectively. Petersen et al. (2015) reported a similar percentage of water sources exceeding maximum tolerable levels for $\mathrm{Na}(42 \%)$, sulfate $(37 \%)$, and $\mathrm{pH}(36 \%)$. Water sources in the study by Petersen et al. (2015) were sampled throughout production years at the Fort Keogh Livestock and Range Research Laboratory located near Miles City, Montana. In cases when Na concentrations in water are excessive, animals may refuse a salt-mineral mix offered ad libitum (Petersen et al., 2015), potentially ex- 
Table 7. Average and range of concentrations, percentage of samples exceeding the maximum upper level, and concentration at the maximum upper limit for water minerals, compounds, total dissolved solids (TDS), and $\mathrm{pH}$ evaluated from 20 ranches

\begin{tabular}{lrccc} 
Variable & Average & \multicolumn{5}{c}{$\begin{array}{c}\text { Samples exceeding } \\
\text { maximum upper } \\
\text { limit for livestock, \% }\end{array}$} & $\begin{array}{c}\text { Maximum } \\
\text { upper limit }\end{array}$ \\
\hline $\mathrm{Ca}, \mathrm{mg} / \mathrm{kg}$ & 58.42 & $1.21-153.00$ & 0 & 200 \\
$\mathrm{Cu}, \mathrm{mg} / \mathrm{kg}$ & 0.01 & $\mathrm{ND}-0.08$ & 0 & 0.50 \\
$\mathrm{Cl}, \mathrm{mg} / \mathrm{kg}$ & 27.55 & $1.00-205.00$ & 0 & 300 \\
$\mathrm{Fe}, \mathrm{mg} / \mathrm{kg}$ & 0.12 & $\mathrm{ND}-1.11$ & 10 & 0.40 \\
$\mathrm{Mg}, \mathrm{mg} / \mathrm{kg}$ & 35.76 & $0.35-177.00$ & 5 & 100 \\
$\mathrm{Na}, \mathrm{mg} / \mathrm{kg}$ & 238.83 & $4.16-1070.00$ & 40 & 300 \\
$\mathrm{Nitrate}, \mathrm{mg} / \mathrm{kg}$ & 6.88 & $\mathrm{ND}-93.00$ & 0 & 100 \\
Sulfate, $\mathrm{mg} / \mathrm{kg}$ & 373.26 & $\mathrm{ND}-2,720.00$ & 35 & 300 \\
$\mathrm{TDS}, \mathrm{mg} / \mathrm{kg}$ & $1,007.17$ & $164.00-3520.00$ & 5 & 3,000 \\
$\mathrm{pH}$ & 7.78 & $7.00-8.75$ & 20 & 8.50 \\
\hline${ }^{1} \mathrm{ND}=\mathrm{not}$ detectable in laboratory analysis. & \\
${ }^{2} \mathrm{Maximum}$ upper levels are from the study by Socha et al. (2003). \\
\multicolumn{7}{l}{}
\end{tabular}

acerbating intake variation within flocks. Increased concentration and intake of $\mathrm{S}$ in water and feed may reduce Se bioavailability, because these 2 minerals have similar physical and chemical properties (Hintz and Hogue, 1964; Spears, 2003). Sulfur interacts with several other minerals including $\mathrm{Cu}$, Mo, and $\mathrm{Zn}$, and high concentrations of sulfates in water sources could act as an antagonist, possibly causing deficiencies in the current study. An acceptable $\mathrm{pH}$ range for livestock water is 6 to 8.5 (Socha et al., 2003). Additionally, high levels of $\mathrm{Ca}, \mathrm{P}, \mathrm{Mg}$, and $\mathrm{S}$ dissolved in drinking water can limit water intake, therefore limiting DMI (NRC, 2007). Total dissolved solid concentrations of 2,000 to $4,900 \mathrm{mg} / \mathrm{kg}$ may cause temporary water refusal, and this is more common in younger animals (NRC, 2007). Water with total dissolved solid concentrations between 4,900 and $7,000 \mathrm{mg} / \mathrm{kg}$ should be used with caution, and any water sources with greater levels should be avoided. Results from the present study outline the importance of regularly testing drinking water to account for characteristics that could influence mineral supplementation management programs.

\section{Relationships Among Water Characteristics and Serum Trace Mineral Concentrations}

Estimated Pearson correlation coefficients between ranch mean serum Se and Zn concentrations and water characteristics are displayed in Table 8. Serum Se was positively and moderately correlated $(P<0.08)$ with water $\mathrm{Na}$ and total dissolved solids. All other Pearson correlation coefficients were not different from zero $(P>0.10)$. This could be due to the fact that serum mineral status may be less affected by water characteristics or that serum is not the appropriate indicator for detection of water's influence on some minerals.

\section{IMPLICATIONS}

Results from the current study provide insight on serum trace mineral concentrations in a subpopulation of developing ram lambs in addition to the broader concern that $33 \%$ of ranches did not provide mineral supplement. Supplementation of trace minerals had an influence on serum Se concentrations. On average, serum Se concentrations were lower in animals located in western Montana along the Rocky Mountain front, which was likely due to soil and forage Se deficiencies. Selenium and Zn were the 2 most deficient and marginally deficient minerals across

Table 8. Estimated Pearson correlation coefficients between ranch mean serum Se and $\mathrm{Zn}$ concentration and water minerals, compounds, total dissolved solids (TDS), and $\mathrm{pH}$ evaluated from 20 ranches

\begin{tabular}{llr} 
& \multicolumn{2}{c}{ Trace mineral } \\
\cline { 2 - 3 } Water characteristic & Se & \multicolumn{1}{c}{ Zn } \\
\hline $\mathrm{Ca}$ & 0.19 & -0.23 \\
$\mathrm{Cu}$ & 0.12 & 0.10 \\
$\mathrm{Cl}$ & 0.36 & 0.10 \\
$\mathrm{Fe}$ & 0.20 & -0.27 \\
$\mathrm{Mg}$ & 0.35 & -0.13 \\
$\mathrm{Na}$ & $0.58^{*}$ & -0.13 \\
$\mathrm{Nitrate}$ & 0.23 & 0.12 \\
Sulfate & 0.40 & -0.19 \\
$\mathrm{TDS}$ & $0.60^{*}$ & -0.20 \\
pH & -0.08 & 0.38 \\
\hline
\end{tabular}

*Estimated Pearson correlation coefficient is different from zero $(P<0.05)$. 
Montana ram lamb populations, and additional supplementation of these trace minerals is recommended. Additional factors that may influence mineral status variation include individual intake, forage species maturity, season, bioavailability of trace mineral chemical form, and mineral antagonists.

\section{ACKNOWLEDGMENTS}

Support for this study was provided by the National Sheep Industry Improvement Center (2016-81-0045) and Montana State Agricultural Experiment Station. The authors expresses gratitude to Sarah Spear (Spear Sheep Ranch, Buffalo, MT) and Monica Ebert (Core Merino, Port Elizabeth, South Africa) for their assistance.

\section{LITERATURE CITED}

Ademi, A., A. Bernhoft, E. Govasmark, H. Bytyqi, T. Sivertsen, and B. R. Singh. 2017. Selenium and other mineral concentrations in feed and sheep's blood in Kosovo. Transl. Anim. Sci. 1:97-107.

Aliarabi, H., A. Fadayifar, M. M. Tabatabaei, P. Zamani, A. Bahari, A. Farahavar, and A. H. Dezfoulian. 2015. Effect of zinc source on hematological, metabolic parameters and mineral balance in lambs. Biol. Trace Elem. Res. 168:82-90.

Apgar, J. 1992. Zinc and reproduction: An update. J. Nutr. Biochem. 3:266-278.

Bennetts, H., and F. E. Chapman. 1937. Copper deficiency in sheep in western Australia: A preliminary account of the aetiology of enzootic ataxia of lambs and an anaemia of ewes. Aust. Vet. J. 13:138-149.

Berg, J. M. 1990. Zinc fingers and other metal-binding domains. Elements for interactions between macromolecules. J. Biol. Chem. 265:6513-6516.

Berger, L. L. 1996. Variation in the trace mineral content of feedstuffs. Prof. Anim. Sci. 12:1-5.

Black, J. R., C. B. Ammerman, P. R. Henry, and R. C. Littell. 1985. Influence of dietary manganese on tissue trace mineral accumulation and depletion in sheep. Can. J. Anim. Sci. 65:653-658.

Bowman, J. G. P., and B. F. Sowell. 1997. Delivery method and supplement consumption by grazing ruminants: A review. J. Anim. Sci. $75: 543-550$.

Buck, W. B., and R. M. Sharma. 1969. Copper toxicity in sheep. Iowa State Univ. Vet. 31:1.

Burton, D. J., P. A. Ludden, R. H. Stobart, and B. M. Alexander. 2015. 50 years of the Wyoming ram test: How sheep have changed. J. Anim. Sci. 93:1327-1331. https://doi.org/10.2527/jas.2014-8150.

Cloete, S. W., F. E. Van Niekerk, M. Young, G. D. Van Der Merwe, and J. Clark. 1999. The application of selenium fertilizer for the correction of marginal deficiencies in grazing sheep. J. S. Afr. Vet. Assoc. 70:107-111.

Dargatz, D. A., and P. F. Ross. 1996. Blood selenium concentrations in cows and heifers on 253 cow-calf operations in 18 states. J. Anim. Sci. 74:2891-2895.

de Sousa, I. K., A. H. Hamad Minervino, S. Sousa Rdos, D. F. Chaves, H. S. Soares, O. Barros Ide, C. A. De Araujo, R. A. Junior, and E. L. Ortolani. 2012. Copper deficiency in sheep with high liver iron accumulation. Vet. Med. Int. https://doi.org/10.1155/2012/207950.
FDA. 2004. Title 21. Food and Drugs: Food Additives Permitted in Feed and Drinking Water of Animals. US Food Drug Admin., Silver Spring, MD.

Gabbedy, B. 1971. Effect of selenium on wool production, body weight and mortality of young sheep in Western Australia. Aust. Vet. J. $47: 318-322$.

Gibbons, R. A., S. N. Dixon, K. Hallis, A. M. Russell, B. F. Sansom, and H. W. Symonds. 1976. Manganese metabolism in cows and goats. Biochim. Biophys. Acta 444:1-10.

Grace, N. D., and J. Lee. 1990. Effect of Co, Cu, Fe, Mn, Mo, Se, and $\mathrm{Zn}$ supplementation on the elemental content of soft tissues and bone in sheep grazing ryegrass/white clover pasture. New Zealand J. Agric. Sci. 33:635-647.

Grings, E. E., M. R. Haferkamp, R. K. Heitschmidt, and M. G. Karl. 1996. Mineral dynamics in forages of the northern Great Plains. J. Range Manage. 49:234-240. https://doi.org/10.2307/4002884.

Hall, J. A., R. J. Van Saun, T. Nichols, W. Mosher, and G. Pirelli. 2009. Comparison of selenium status in sheep after short-term exposure to high-selenium-fertilized forage or mineral supplement. Small Rumin. Res. 82:40-45.

Hall, J. A., W. R. Vorachek, W. C. Stewart, M. E. Gorman, W. D. Mosher, G. J. Pirelli, and G. Bobe. 2013. Selenium supplementation restores innate and humoral immune responses in footrot-affected sheep. PLoS One 8:e82572. https://doi.org/10.1371/journal.Pone 0082572

Herdt, T. H., and B. Hoff. 2011. The use of blood analysis to evaluate trace mineral status in ruminant livestock. Vet. Clin. North Am. Food Anim. Pract. 27:255-283.

Hintz, H. F., and D. E. Hogue. 1964. Effect of selenium, sulfur, and sulfur amino acids on nutritional muscular dystrophy in the lamb. J. Nutr. 82:495-498

Jones, D. G., and N. F. Suttle. 1981. Some effects of copper deficiency on leucocyte function in sheep and cattle. Res. Vet. Sci. 31:151-156.

Jones, G. B., and B. F. Tracy. 2015. Evaluating seasonal variation in mineral concentration of cool-season pasture herbage. Grass Forage Sci. 70:94-101.

Karn, J. F., and L. Hofmann. 1990. Comparison of the copper and molybdenum status of yearling steers grazing reclaimed mined-land and native range. J. Range Manage. 43:69-72.

Keady, T. W. J., J. P. Hanrahan, and S. P. Fagan. 2017. Cobalt supplementation, alone or in combination with vitamin $\mathrm{B}_{12}$ and selenium: Effects on lamb performance and mineral status. J. Anim. Sci. 95:379-386.

Kennedy, D. G., W. J. Blanchflower, J. M. Scott, D. G. Weir, A. M. Molloy, S. Kennedy, and P. B. Young. 1992. Cobalt-vitamin B-12 deficiency decreases methionine synthase activity and phospholipid methylation in sheep. J. Nutr. 122:1384-1390.

Kincaid, R. 2000. Assessment of trace mineral status of ruminants: A review. J. Anim. Sci. 77:1-10.

Kumar, N., R. P. Verma, L. P. Singh, V. P. Varshney, and R. S. Dass. 2006. Effect of different levels and sources of zinc supplementation on quantitative and qualitative semen attributes and serum testosterone level in crossbred cattle (Bos indicus $\times$ Bos taurus) bulls. Reprod. Nutr. Dev. 46:663-675.

Langlands, J. P., J. E. Bowles, G. E. Donald, and A. J. Smith. 1984. Deposition of copper, manganese, selenium and zinc in Merino sheep. Aust. J. Agric. Res. 35:701-707.

Langlands, J. P., G. E. Donald, J. E. Bowles, and A. J. Smith. 1991. Subclinical selenium insufficiency. 3. The selenium status and productivity of lambs born to ewes supplemented with selenium. Aust. J. Exp. Agric. 31:37-43. 
Martin, G. B., and C. L. White. 1992. Effects of dietary zinc deficiency on gonadotrophin secretion and testicular growth in young male sheep. J. Reprod. Fertil. 96:497-507.

Martin, G. B., C. L. White, C. M. Markey, and M. A. Blackberry. 1994. Effects of dietary zinc deficiency on the reproductive system of young male sheep: Testicular growth and the secretion of inhibin and testosterone. J. Reprod. Fertil. 101:87-96.

Masters, D. G., D. I. Paynter, J. Briegel, S. K. Baker, and D. B. Purser. 1988. Influence of manganese intake on body, wool and testicular growth of young rams and the concentration of manganese and activity of manganese enzymes in tissues. Aust. J. Agric. Res. 39:517-524.

Mathis, C., and J. Sawyer. 2004. New Mexico forage mineral survey. Proc. West. Sec. Am. Soc. Anim. Sci. 55:182-185.

McDonald, J. 1975. Selenium-response unthriftiness of young Merino sheep in central Victoria. Aust. Vet. J. 51:433-435.

McDowell, L. R. 1996. Feeding minerals to cattle on pasture. Anim. Feed Sci. Technol. 60:247-271.

McDowell, L. R. 2017. Mineral Nutrition History, The Early Years. 1st ed. Design Publ. Inc., Sarasota, FL. https://doi.org/10.21899/978 -1506904580 .

Menzies, P. I., H. Boermans, B. Hoff, T. Durzi, and L. Langs. 2003. Survey of the status of copper, interacting minerals, and vitamin E levels in the livers of sheep in Ontario. Can. Vet. J. 44:898-906.

Notter, D. R. 1998. The U.S. National Sheep Improvement Program: Across-flock genetic evaluations and new trait development. J. Anim. Sci. 76:2324-2330.

NRC. 1983. Selenium in Nutrition. Natl. Acad. Press, Washington, DC.

NRC. 2005. Mineral Tolerance of Domestic Animals. Natl. Acad. Press, Washington, DC.

NRC. 2007. Nutrient Requirements of Small Ruminants: Sheep, Goats, Cervids, and New World Camelids. Natl. Acad. Press, Washington, DC.

Page, C. P., I. McGregor, M. L. Van Emon, T. W. Murphy, C. K. Larson, J. G. Berardinelli, and W. C. Stewart. 2017. Effects of zinc source and dietary concentration on zinc status, growth performance, and wool characteristics in developing rams. Proc. West. Sec. Am. Soc. Anim. Sci. 68:136-140.

Petersen, M. K., J. M. Muscha, J. T. Mulliniks, R. C. Waterman, A. J. Roberts, and M. J. Rinella. 2015. Sources of variability in livestock water quality over 5 years in northern Great Plains. J. Anim. Sci. 93:1792-1801.

R Core Team. 2016. R: A language and environment for statistical computing. R Found. Stat. Comput., Vienna, Austria. Accessed Jul. 31, 2018. https://www.R-project.org/.

Rauzi, F., L. I. Painter, and A. K. Dobrenz. 1969. Mineral and protein contents of Blue Grama and Western Wheatgrass (contenido de minerals y proteinase n el Navajita Azul (Bouteloua gracilis) y Western Wheatgrass (Agropyron smithii)). J. Range Manage. 1:47-49.

Rojas, L., L. McDowell, R. Cousins, F. Martin, N. Wilkinson, A. B. Johnson, and J. Velasquez. 1995. Relative bioavailability of two organic and two inorganic zinc sources fed to sheep. J. Anim. Sci. 73:1202-1207.

Slen, S., A. Demiruren, and A. Smith. 1961. Note on the effects of selenium on wool growth and body gains in sheep. Can. J. Anim. Sci. 41:263-265.
Smith, D. B., W. F. Cannon, L. G. Woodruff, F. Solano, and K. J. Ellefsen. 2014. Geochemical and Mineralogical Maps for Soils of the Conterminous United States. US Geological Survey, Reston, VA. https://doi.org/10.3133/ofr20141082.

Socha, M. T., S. M. Ensley, D. J. Tomlinson, and A. B. Johnson. 2003 Variability of water composition and potential impact on animal performance. Pages 85-96 in Proc. Intermt. Nutr. Conf., Salt Lake City, UT. Utah State Univ., Logan.

Spears, J. W. 2003. Trace mineral bioavailability in ruminants. J. Nutr. 133:1506S-1509S.

Spears, J. W., and W. P. Weiss. 2008. Role of antioxidants and trace elements in health and immunity of transition dairy cows. Vet. J. 176:70-76.

Stewart, W. C., G. Bobe, G. J. Pirelli, W. D. Mosher, and J. A. Hall. 2012a. Organic and inorganic selenium: III. Ewe and progeny performance. J. Anim. Sci. 90:4536-4543. https://doi.org/10.2527/jas .2011-5019.

Stewart, W. C., G. Bobe, W. R. Vorachek, G. J. Pirelli, W. D. Mosher, T. Nichols, R. J. Van Saun, N. E. Forsberg, and J. A. Hall. 2012b. Organic and inorganic selenium: II. Transfer efficiency from ewes to lambs. J. Anim. Sci. 90:577-584.

Suttle, N. F. 2010. Mineral Nutrition of Livestock. 4th ed. CAB Int., Wallingford, UK. https://doi.org/10.1079/9781845934729.0000.

Suttle, N. F., and K. W. Angus. 1976. Experimental copper deficiency in the calf. J. Comp. Pathol. 86:595-608.

Underwood, E. J. 1981. The Mineral Nutrition of Livestock. p. 10. Commonwealth Agric. Bureaux, Slough, UK.

Underwood, E. J., and M. Somers. 1969. Studies of zinc nutrition in sheep. I. The relation of zinc to growth, testicular development, and spermatogenesis in young rams. Aust. J. Agric. Res. 20:889-897.

USDA-NASS. 2017. US Sheep and Goat Report. Accessed Mar. 10 2016. http://usda.mannlib.cornell.edu/usda/current/SheeGoat/ SheeGoat-01-31-2017.pdf.

Venables, W. N., and B. D. Ripley. 2002. Modern Applied Statistics with S. 4th ed. Springer, New York, NY.

Vermunt, J. J., and D. M. West. 1994. Predicting copper status in beef cattle using serum copper concentrations. N. Z. Vet. J. 42:194-195.

Wahlen, R., L. Evans, J. Turner, and R. Hearn. 2005. The use of collision/reaction cell ICP-MS for the determination of 18 elements in blood and serum samples. Spectroscopy (Springf.) 20:12.

Wegner, T. N., D. E. Ray, C. D. Lox, and G. H. Stott. 1973. Effect of stress on serum zinc and plasma corticoids in dairy cattle. J. Dairy Sci. 56:748-752.

Weiss, W. P., J. S. Hogan, K. L. Smith, and K. H. Hoblet. 1990. Relationships among selenium, vitamin E, and mammary gland health in commercial dairy herds. J. Dairy Sci. 73:381-390. https://doi.org/10 .3168/jds.S0022-0302(90)78684-5.

White, C., G. Martin, P. Hynd, and R. Chapman. 1994. The effect of zinc deficiency on wool growth and skin and wool follicle histology of male Merino lambs. Br. J. Nutr. 71:425-435.

Williams, R. J. P., and J. J. R. F. Da Silva. 2002. The involvement of molybdenum in life. Biochem. Biophys. Res. Commun. 292:293-299. 